\title{
CD27 wt Allele
}

National Cancer Institute

\section{Source}

National Cancer Institute. CD27 wt Allele. NCI Thesaurus. Code C104072.

Human CD27 wild-type allele is located in the vicinity of $12 \mathrm{p} 13$ and is approximately $7 \mathrm{~kb}$ in length. This allele, which encodes CD27 antigen protein, plays a role in regulating B-cell activation and immunoglobulin synthesis. 